\title{
SCIENTIFIC WORK DISSEMINATION IN INDONESIA: A PILOT STUDY
}

\author{
Katrin Setio Devi ${ }^{1 *}$, Rahmi $^{2}$, Hermin Triasih $^{3}$ \\ 1,2,3 Department of Library and Information Science, Universitas Indonesia \\ ${ }^{3}$ The Center for Scientific Data and Documentation, Indonesian Institute of Sciences \\ *Correspondence: katrin.setio@ui.ac.id
}

Submission: 05-06-2020; Review: 28-08-2020; Accepted: 07-09-2020; Revised: 02-11-2020

\begin{abstract}
This article describes the research dissemination activities of lecturers and researchers in Indonesia. Data were collected through an online survey with 39 questions distributed to respondents via social media from 21 to 31 July 2020. Thirty out of 77 respondents completed the online questionnaire. The results identified variables, such as resources available for dissemination, planning and targeting dissemination activity, evaluating the effects, and capturing research influence. The results revealed that almost all respondents realised the importance of dissemination and wanted to participate. The results show that $80 \%$ dissemination activities are conducted through academic journals. Assistance and instruction from specialize divisions or institutions are needed for the dissemination process so that results are maximally employed and so that the role of research is increased in policymaking. Although only $3 \%$ researchers evaluated their research, when asked about the influence of their research, most researchers provided examples of the influence of their research. Researchers understand the importance of dissemination and have been putting it into practice. Researchers require clear guidance from institutions that can assist them in the dissemination process from the planning stage to dissemination.
\end{abstract}

\begin{abstract}
ABSTRAK
Artikel ini menjelaskan kegiatan diseminasi penelitian dosen dan peneliti di Indonesia. Pengumpulan data dilakukan melalui survei online dengan 39 pertanyaan yang dibagikan kepada responden melalui media sosial dari tanggal 21 hingga 31 Juli 2020. Tiga puluh dari 77 responden mengisi kuesioner online. Hasil penelitian mengidentifikasi variabel, seperti sumber daya yang tersedia untuk diseminasi, perencanaan dan penargetan kegiatan diseminasi, mengevaluasi efek, dan menangkap pengaruh penelitian. Hasil penelitian menunjukkan bahwa hampir semua responden menyadari pentingnya sosialisasi dan partisipasi. Hasil menunjukan $80 \%$ kegiatan sosialisasi dilakukan melalui jurnal akademik. Dibutuhkan pendampingan dan arahan dari divisi atau lembaga khusus untuk proses diseminasi agar hasilnya dapat dimanfaatkan secara maksimal dan agar peran penelitian dalam pembuatan kebijakan semakin meningkat. Meskipun hanya 3\% peneliti yang mengevaluasi penelitiannya, namun ketika ditanya tentang pengaruh penelitiannya, sebagian besar peneliti dapat memberikan contoh pengaruh penelitiannya. Peneliti memahami pentingnya diseminasi dan telah mempraktikkannya. Peneliti membutuhkan arahan yang jelas dari lembaga yang dapat mendampingi mereka dalam proses diseminasi mulai dari tahap perencanaan hingga diseminasi.
\end{abstract}

Keywords: Data dissemination; Scientific work; Researchers; Journal; Indonesia

\section{INTRODUCTION}

Scientific papers play a significant role as evidence of scientific research results that can be disseminated to the public and are widely recognition globally. There are 4,670 higher education institutions, such as universities, institutes, schools of higher learning, academies, community colleagues, and polytechnics, with approximately 300,000 lecturers (Dikti, 2018). About 10,000 researchers across institutions and ministries in Indonesia are expected to produce scientific work and publications (Jatmika, 2017). Further, the Indonesian government has issued several regulations demonstrating the necessity of conducting research activities and spreading the results of studies to policy officers, other researchers, academics, practitioners, and the public. These regulations include Law Number 11 of 2019 concerning the national system of science and 
technology, Law Number 12 of 2012 concerning higher education, and Presidential Regulation Number 18 of 2020 concerning the 2020-2024 National Medium-Term Development Plan.

Although regulations support dissemination activities, grant providers have not explicitly provided a flow or systematics for the dissemination process (Ristek-BRIN, 2020). Grant providers understand that dissemination of scientific work is a shared responsibility, yet they do not fully understand the dissemination activities and their part in these activities (Sundari, 2007). The expectation gap between grant providers and lecturers or researchers must be fulfilled regarding the roles and contributions in dissemination activities.

Previous research by Wilson et al. (2010) has shown that most researchers in the UK focus on academic publications where the most effective dissemination method has not been found to provide the maximum effects or return on investment in public funds for the conducted research. Through the research by Wilson et al. (2010), this pilot study uses a similar research approach to describe the planning process that involves the targets and supporting regulations or policies for dissemination practice, particularly in Indonesia.

This research aims to describe how 30 lecturers and researchers working across Indonesia disseminate the findings of their research. This study also sought to determine the following: (1) whether we could identify any explicit/implicit use of existing knowledge and theory relating to research dissemination; (2) whether researchers knew of or could describe any effects their activities have had on policy and practice, and 3) whether we could identify any dissemination factors associated with the respondents' ability to report research influence (Wilson et al., 2010). This research was conducted in a reasonably short period with a plan to collect data in 10 days. Considering that the research population is national in scale, and the data collection takes time, and further research is needed.

\section{LITERATURE REVIEW}

Dissemination is an activity aimed at target groups or individuals so that they will be exposed, receive, and use the information. Dissemination is also referred to as the process of distributing information that is planned, directed, and managed so that information sharing is created with the ultimate goal of discussing the information (Widyastuti, 2019). Wilson et. al. (2010) define dissemination as a planned process that involves the perceptions or responses of the target audience and the existence of planning in which the research findings will be disseminated. Audiences could come from practitioners, governments or policy makers.

The information disseminated will serve as a basis for policy making or practical guidance. Ensuring that research results will be used, research must develop a dissemination plan that describes how the project results will be shared with, perhaps for governments, stakeholders, organizations, practitioners or individuals. Thus, it can be concluded that dissemination is a systematic distribution of information and circulate with careful planning methods and foresight through discussions or other forums that are deliberately scheduled. Dissemination planning must address the objectives of information dissemination, audiences for dissemination, information to be shared, methods of delivery, time for the dissemination agenda, and processes for evaluating the success of dissemination efforts (Brownson, et.al, 2018)

\section{METHOD}

Descriptive quantitative research was used on this research which aims to describe and to explain the dissemination of scientific works in Indonesia (Field, 2013). The data were collected through a questionnaire using the surveymonkey.com platform from 21 to 31 July 2020. The data collection method was conducted through an online survey because the study population was national in scale, and many questions were asked (Krosnick, et al. 2015). Thirty respondents who 
work as lecturers and researchers in Indonesia completed this questionnaire without any limitations regarding the scientific domain. The estimation of the time to complete the questionnaire in English was about 20 minutes. The questionnaire was distributed through social media assistance, such as WhatsApp, Instagram, Facebook, and email. Any questionnaires not returned by 31 July 2020 were deemed to be nonresponses.

The distributed online questionnaire was adopted from Wilson et al. (2010) with a few adjustments, including replacing words in several sections because previous studies focused on researchers in the medical (clinical) realm. We generalised the questionnaire, considering that the population of this study comprises all researchers and lecturers in Indonesia. The questionnaire was divided into three parts, in which several questions aim to determine the following:

- researchers' views and attitudes about dissemination and their methods of conducting dissemination (questions 3 to 20);

- types of research grants that respondents have received that examine the influence of research in policy making, standardization, and guidelines for related agencies or grantgiving organisations (questions 21 to 35);

- respondents' demographic characteristics (questions 36 to 39).

The results of this study were analysed using the dissemination theory and were compared with previous studies in the same direction as this study. For the final stage, whether a relationship exists between the three categories or the stage of the questions in the survey was determined.

\section{RESULTS AND DISCUSSION}

The population of lecturers and researchers in Indonesia based on Dikti (2018) and Jatmika (2017) is approximately 310,000 people. The sample selection was carried out using the accidental sampling technique in social sciences (Akdon \& Riduwan, 2008; Field, 2013). Thirty out of 77 completed questionnaires were returned, resulting in a completion rate of $38.96 \%$. According to Akdon \& Riduwan (2008), a sample of 30 respondents as a representative of the population is valid. The gender proportion of respondents was 16 females and 14 males, and the ages of respondents were split into groups of less than or equal to 30 years old $(n=13)$ and older than $30(n=17)$. Twenty-eight respondents stated that the dissemination of research findings was formally part of their role, whereas two respondents stated that it was not. Further, 26 respondents thought the dissemination of research findings should be officially part of their role, while three respondents said that it was not, and one respondent was not sure.

\subsection{Importance of Dissemination}

Research dissemination was rated as very important or important by 29 respondents, all of whom thought that it was part of their role as a lecturer or a researcher. Only one respondent felt unsure that research dissemination was important to their research. Figure 1 presents the reasons selected from a predefined list of 12 options adapted from Wilson et al. (2010) by respondents for disseminating the findings of their research. Of the reasons given, 23 respondents indicated that transferring research to practice was the most important reason, followed by those who felt raising awareness of the findings $(n=21)$ and promoting public understanding of science $(n=16)$ were the most important reasons. 


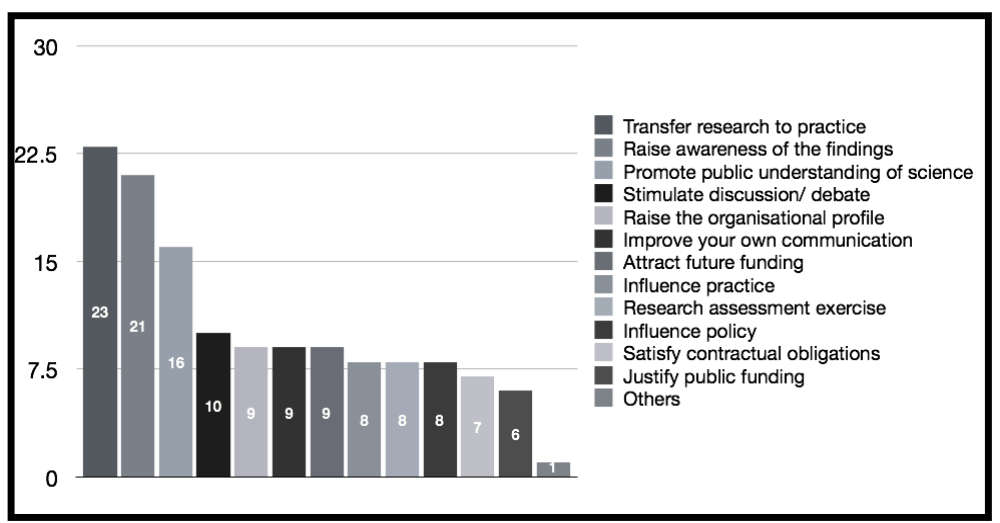

Figure 1. Reasons for disseminating the findings of research

The results reveal that the majority of respondents were aware of the importance of disseminating the results of the research they have done. Regarding the reasons for dissemination activities, the results indicate a difference from Wilson's previous research. Previous research has shown that the reason for the second-largest ranking of researchers for conducting dissemination is so that it can be used as a consideration in policymaking. In this study, this reason ranked third from the bottom. In fact, in retrospect, the government's goal of providing funds of 35.7 trillion for the research sector is for consideration in policymaking. This can be used as a further study, whether this affects the majority of policies in Indonesia are not based on scientific evidence from research, as suggested by Asmara \& Handoyo (2015).

\subsection{Resources Available for Dissemination}

The process of research dissemination of the work by the respondents' units or departments is very important to 16 respondents, important to 13 respondents, and somewhat important to one respondent. Nine respondents stated that they had a dedicated person or team responsible for dissemination-related activities within their unit or department, such as librarians, research institutions, and community service (Lembaga Penelitian dan Pengabdian kepada Masyarakat/LPPM), institutes for learning development and quality assurance (Lembaga Pengembangan Pembelajaran dan Penjaminan Mutu/LP3M), and a member of the research team with specific skills. In comparison, 21 respondents stated no or not sure. The time proportion that they dedicate to dissemination-related activities was $<10 \%(\mathrm{n}=12)$ and $>10 \%(\mathrm{n}=18)$.

The data indicate that the existence of a particular division or section to assist researchers in disseminating research has not been maximally fulfilled. This contrasts with the respondents' recognition that dissemination must be conducted. Our study indicates a similarity to the work by Wilson et al. (2010), for instance, the clarity of institutions and divisions regarding dissemination of scientific work. The direction of development activities not based on research is inaccurate, and even the development does not provide real benefits to the community and region. The collaboration between grantees and the Research and Development Agency or Regional Development Planning Agency is needed to create an appropriate channel for disseminating research results. As Coll \& Vicente (2007) and McVay et al. (2016) stated there must be a platform or institution to support the smooth running of dissemination activities. These institutions can guide researchers in the agenda of disseminating their research results.

\subsection{Planning and Targeting Dissemination Activity}

Seventeen respondents indicated that their unit or departments had a formal communication or dissemination strategy, whereas seven respondents indicated no or not sure $(n=6)$. Ten 
respondents stated that they sometimes referred to guidance or used a framework to plan their dissemination activity. A further eight respondents stated that they usually did so, whereas one respondent indicated always, five indicated rarely, five indicated never, and one indicated not sure. Fourteen respondents plan dissemination-related activities at the final report stage, whereas the other respondents indicated planning at the proposal stage $(n=6)$, at the research-formulation stage $(n=4)$, during all stages of the process $(n=3)$, during the draft report stage $(n=2)$, and during the research process $(n=1)$. Seventeen respondents usually thought about people who need to know about the findings and who are most likely to be influenced or will influence others, whereas other respondents indicated always $(n=6)$, sometimes $(n=5)$, rarely $(n=1)$, or never (n $=1$ ) on this question. Twenty-nine respondents indicated that, as part of research dissemination activities, they consider how audiences or groups would like to access, read, and use research findings. Only one respondent stated that they never think about this. Eight respondents sometimes produce research summaries or key messages written for specific audiences or groups (such as policymakers, service managers, or general practitioners), whereas other respondents indicated that they rarely $(n=8)$, never $(n=8)$, always $(n=3)$, or usually $(n=3)$ do this. Most respondents $(\mathrm{n}=22)$ also indicated that part of their dissemination planning involved considering whether to target specific audiences (such as policymakers, service managers, or general practitioners). Eight respondents stated that they never produce a research summary or key message written for specific audiences.

Figure 2 illustrates the communication channels used by respondents. The additional channels include dissemination via class lecture $(n=1)$. Of the channels used, 26 respondents felt that dissemination via academic journals generally had the most influence. The results reveal that almost half of the respondents plan a dissemination agenda that includes the target audience. Researchers must make a presentation that is readily accepted regarding conducting the planning and targeting dissemination activities to policy officials. Leni et al. (2018) argued that one of the obstacles in considering research results in shaping public policy is the difference in views between researchers and policymakers. There is a gap between researchers and policymakers in terms of language, culture, and thought. Researchers are expected to have political and practical knowledge for implementation.

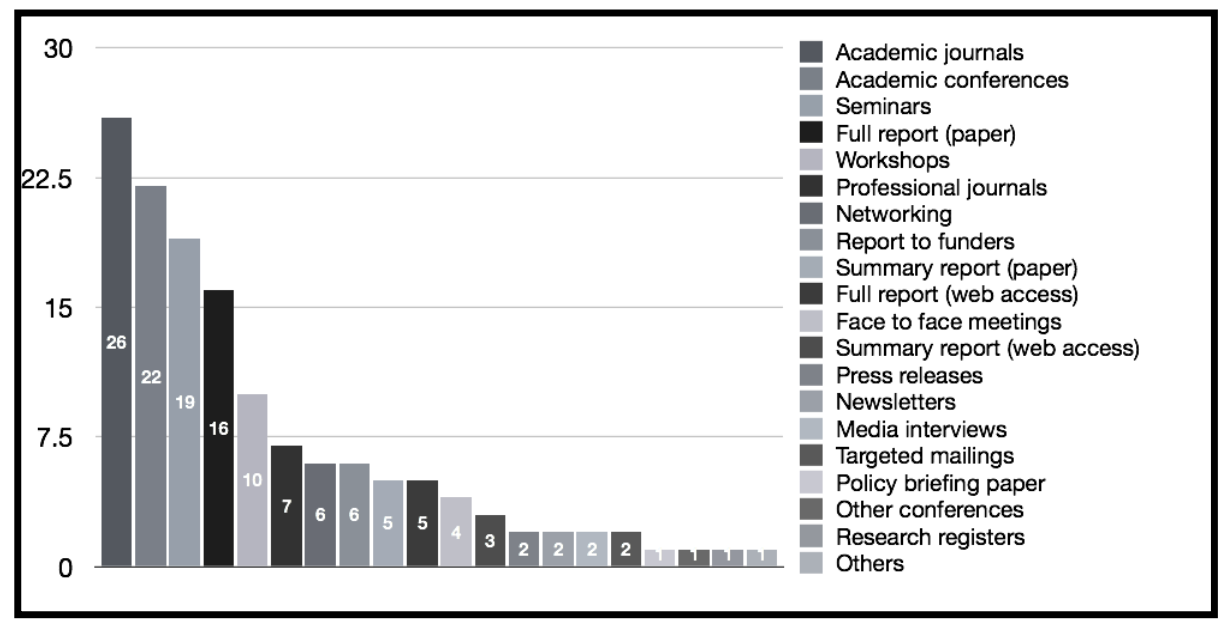

Figure 2. Communication channels used by researchers

\subsection{Evaluating the Influence}

Respondents were asked how they recorded formal or informal feedback about the influence of their research. Thirteen respondents stated that they sometimes evaluated the success or influence of research dissemination activities, whereas other respondents indicated usually $(\mathrm{n}=$ $5)$, rarely $(n=5)$, always $(n=4)$, or never $(n=3)$. Overall, most respondents $(n=20)$ rated their 
current research dissemination activities as either adequate or good; only one rated them as excellent. A further nine respondents rated their current activities as poor.

Based on the obtained data, only $3 \%$ of respondents always evaluate the influence of their research, and this result is different from the research by Wilson, which indicated 13\%. In terms of measuring the level of dissemination practice, these two studies show a difference of $14 \%$, and health researchers in the UK are superior in dissemination practices. However, similarities exist between these two studies, namely the scientific communication channels chosen to disseminate the results of their studies through academic journals. These findings can be used as further research to determine the trends of researchers in choosing the form of academic journals to disseminate evaluations. This study was to observe whether they included an academic journal with a paid or open access system and its effect on the h-index. Scientific communication for dissemination activities conducted using an open-access database provides more opportunities for use by users, including policy officials and practitioners (Canessa \& Marco 2008; García-Peñalvo et al., 2010; Garcia \& Cecilia, 2010).

\subsection{Capturing Research Influence}

For the remaining questions, respondents were asked to provide information on the dissemination of a publicly funded research project they had recently completed, and 30 respondents provided some details. Twenty-five respondents indicated that a dissemination plan was produced for the research project. Respondents obtained funding from the government ( $\mathrm{n}=$ 11), universities $(n=11)$, international agencies $(n=4)$, and other independent sources $(n=1)$. However, only seven respondents received advice or support from the funders. The type of support and advice from funders varied and included advice, supervision, and monitoring to publish the research through conferences or journals.

Respondents were then asked whether there were any methods of disseminating research findings that they would like to have used but were unable to do so, and six respondents said yes. For example, these methods include Focus Group Discussion (FGD) on the same topics, open government data public repositories, seminars, public discussion inviting teachers and language policymakers. Respondents were also asked if anything else would have enhanced the influence of their research, and nine respondents said yes. For example, respondents suggested the following:

- using a forum to present the research results in front of related practitioners;

- communicating the research to a broader audience using an easily understandable format (weblog or online magazine);

- using an in-depth presentation of the research processes in class;

- employing research plan management;

- putting the research on the social media of the institution (websites, IG, and others);

- applying research in the industry;

- developing the scale for more significant proceeds at the business level to communicate the methods and issues in a large group;

- using a virtual academic discussion or seminar.

Five respondents stated that their research had been cited in a publication journal, implemented by one of the ministries, students' works, cited on Google Scholar, and by the National Public Library Development Policy. Six respondents stated that their research had or was likely to influence the citation and community discussion, for example, by being a keynote 
speaker in most FGDs, upgrading methods, and by the government using the results of the research to maintain or improve their systems. The study is the primary reference for a particular allocation budget in libraries. Although the research results have not been included in policy documents, the research influences policy changes in reconstructing studies and strategies in one of the subjects regarding literacy skills. Nine respondents stated their research was disseminated by someone else other than themselves (and other investigators).

Respondents were also asked whether the findings of their research had been taken up or used by anyone that they had not anticipated or in any other ways that were not initially anticipated, and one respondent said yes. Nine respondents indicated that international interest and uptake had been greater than originally anticipated. No respondent indicated that the findings of the research had been misrepresented or used in inappropriate ways. Ten respondents received formal or informal feedback about their research on the information recorded for personal use, whereas the other respondents indicated that it was not formally recorded $(n=7)$ or entered into a database $(n=3)$. Figure 3 presents the methods used to publish and disseminate the findings of the research project.

The results reveal that the majority of grants received in research come from public funds. However, the researchers have not been able to disseminate adequately widely; there is a hope that they can disseminate research through FGDs with the same topic, seminars, or discussions with policymakers. The majority of researchers observed the influence of their research regarding the number of citations they received. No study has been used directly in policymaking. However, several respondents stated that their research results were used as part of the references in policymaking. This result is quite different from the results of Wilson's (2010) research, which indicates that research in the UK has been used as a basis for policymaking and standardisation for practice in the health sector. Thus, there must be specific action from the government to collaborate with researchers and research and development to maximise the dissemination of research results so that the results can be used as a basis for policymaking in the context of national development (Leni et al. 2018). Moreover, there must also be communication with practitioners to work together on making standards in various fields, especially for public services.

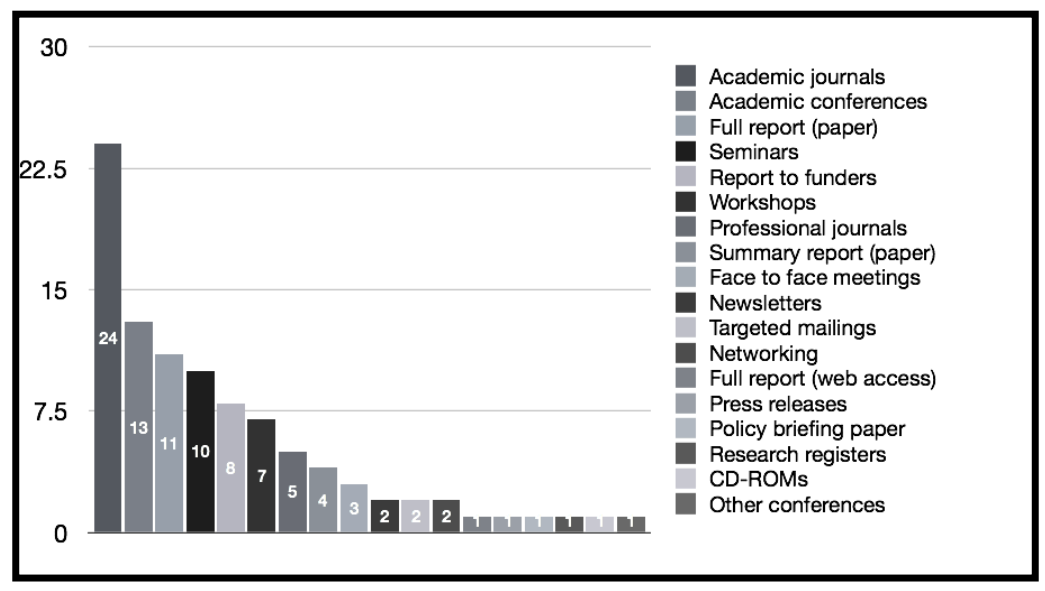

Figure 3. Dissemination and publishing methods used for the research project findings

This study also measured each question included in the third part (see Section 2) concerning the researchers' views and attitudes (18 questions) and the types of research grants that respondents have received (15 questions). Four significant relationships were identified:

1) The significant relationship between a dedicated person or team responsible for disseminating related activities within their unit or organization and their research leading to 
discussion or interaction with policymakers, which has been cited or included in policy documents or is likely to have any other influences on policy $(\chi 2(4, \mathrm{n}=30)=18.324, \mathrm{p}=$ $0.001)$.

2) The significant relationship between the researcher and those who refer to guidance or use a framework to plan dissemination-related activities that the researcher proposed that would have enhanced the influence of this research $(\chi 2(10, n=30)=18.930, p=0.041)$.

3) The significant relationship between the stage in the research process when the researcher usually plans dissemination-related activities and whether the research project findings have been cited in any guidelines $(\chi 2(10, \mathrm{n}=30)=20.598, \mathrm{p}=0.024)$.

4) The significant relationship between researchers who assess who needs to know about the findings and who is most likely to be influenced or would influence others and whether the research is disseminated by anyone else other than the researcher (and other investigators) $(\chi 2(8, \mathrm{n}=30)=16.977, \mathrm{p}=0.030)$.

There is also a significant relationship between age and the following: (1) the importance of the research dissemination process to the work of the researcher's unit or department $(\chi 2(2, n=$ $30)=6.505, \mathrm{p}=0.039)$; and (2) the dedicated person or team responsible for disseminationrelated activities within the researcher's unit or organization $(\chi 2(2, n=30)=7.721, p=0.021)$. The results demonstrate that when a division helps or is responsible for dissemination, the research results influence policymaking. According to the results above, collaboration and the formation of specialize divisions in each agency are necessary to provide guidance and instructions for researchers in conducting dissemination from planning to dissemination practices to increase the influence of research so that research-based policies can be realized.

\section{CONCLUSION}

The findings reveal that researchers require clear instructions regarding how to disseminate research, from planning to publication. The limitations of the conducted research include the small number of samples within the limited survey time (21 to 31 July 2020). In addition, this research is not equipped with a systematic review. According to Roselle and Spray (2012), systematic reviews or literature studies are conducted to evaluate the research. The review can help researchers study the successes and failures of previous research. In addition, literature reviews can also help researchers determine the direction of research to produce better research in the future. Given the limited research time, this study also did not use a Likert scale. From the research results, the level of awareness of lecturers and researchers regarding the importance of disseminating their research results is $97 \%$, and they realized that the dissemination of research results is part of their role. However, $40 \%$ researchers only dedicate $<10 \%$ of their time for this dissemination. Although some researchers have entrusted the process of disseminating their research results to librarians and research institutes, researchers also expect that a particular division can facilitate or assist them in disseminating research results in Indonesia or globally, considering the high costs incurred for the research. If managed properly, the research results can be used for future research development, and repetition of the same research by several researchers due to the lack of an optimal dissemination process of research results or as a basis for making development policies in Indonesia. Policies in Indonesia are not based on research and vice versa. One of the reasons for this was that the research results that should have been used as the basis for policy were not well disseminated. There is a need for a forum that can also communicate research to policymakers so that the results of research conducted in Indonesia can have a real effect on society and development. Further research on the urgency of policies related to data sharing of research results is needed. 


\section{ACKNOWLEDGMENT}

The authors thank the anonymous reviewers for their constructive comments to improve the article. This work was supported in part by the PUTI Q1 contract NKB1450/UN2.RST/HKP.05.00/2020, and by Kappa Sigma Kappa Indonesia (KSKI). Any opinions, findings, and conclusions described here are the authors and do not necessarily reflect those of the sponsors.

\section{REFERENCES}

Akdon, A. \& Riduwan, A. 2008. Rumus dan Data dalam Analisis Statistika. Bandung: Alfabeta.

Asmara, A.Y. \& Handoyo, S. 2015. Pembuatan Kebijakan Berbasis Bukti: Studi Pada Proses Pembuatan Kebijakan Standarisasi Alat dan Mesin Pertanian di Indonesia. STI Policy and Management Journal, 13(1), 38-57.

Canessa, E. \& Zennaro, M. 2008. Science Dissemination Using Open Access. Science Dissemination using Open Access, Trieste, Italy.

Coll, I.S. \& Vicente, J.G. 2007. Dissemination of Information in The Field Of Cultural Heritage Conservation: The Adoption of Open Access in ICOMOS" https://archive.ifla.org/IV/ifla73/papers/154-Coll_Vicente-trans-en.pdf

Field, A. n.d. Discovering Statistics using IBM SPSS Statistics. Sage Publishing.

Garcia, V.J. \& Rantica, C. 2010. Research, Publication and Dissemination of Scientific Literature in The Field of Conservation of Historic Monuments and sites-Results of the ICOMOS Documentation Centre Questionnaire-ICOMOS and Open Access: Setting Up an Institutional and Subject Repository. Technical Report- ICOMOS, Paris, 30p.

García, P., Francisco, J., Figuerola, C.G.D., \& Merlo, J.A. 2010. Open Knowledge: Challenges and Facts. Online Information Review, 34(4), 520-539.

Jatmika, A. 2017. Jumlah Peneliti Indonesia di Urutan Buncit, Apa Tantangannya?. di https://edukasi.kompas.com/read/2017/04/17/15130001/jumlah.peneliti.indonesia.di.urutan.bun cit.apa.tantangannya.?page=all.

Krosnick, J.A., Presser, S., Fealing, K.H., Ruggles, S., \& Vannette, D. 2015. The Future of Survey Research: Challenges and Opportunities. The National Science Foundation Advisory Committee for the Social, Behavioral and Economic Sciences Subcommittee on Advancing SBE Survey Research, 1-15.

Leni, N.E., Widianingsih, I., Alexandri, M.B., \& Ismanto, S.U. 2018. Pemanfataan Hasil Penelitian dalam Kebijakan Publik Studi Kasus pada Badan Penelitian dan Pengembangan Provinsi Sumatera Barat. RESPONSIVE: Jurnal Pemikiran dan Penelitian Administrasi, Sosial, Humaniora, dan Kebijakan Publik, 1(2), 75-80.

McVay, A.B., Stamatakis, K.A., Julie, A.J., Tabak, R.G., \& Brownson, R.C. 2016. The Role of Researchers in Disseminating Evidence to Public Health Practice Settings: A Cross-Sectional Study. Health Research Policy and Systems, 14(1).

Pusdatin-Iptek, K. 2018. Statistik Pendidikan Tinggi Tahun 2018. di pddikti.kemdikbud.go.id.

Spray, S.L. \& Roselle, L. 2012. Research and Writing in International Relations. Boston: Pearson Longman. 
BACA: Jurnal Dokumentasi dan Informasi, 42 (2) Desember 2020, Halaman: 243-251

Wilson, P.M., Petticrew, M., Calnan, M.W., \& Nazareth, I. 2010. Does Dissemination Extend Beyond Publication: A Survey of A Cross-Section of Public Funded Research in the UK. Implementation Science, 5(1). 